\title{
Article
}

\section{Potential Challenges Faced by the U.S. Chemicals Industry under a Carbon Policy}

\author{
Andrea Bassi ${ }^{1,2}$ * and Joel Yudken ${ }^{3}$ \\ 1 Millennium Institute, 2111 Wilson Blvd, Suite 700, Arlington, VA 20001, USA \\ 2 University of Bergen, Postboks 7800, 5020 Bergen, Norway \\ 3 High Road Strategies / 104 N, Columbus Street, Arlington, VA 22203, USA; \\ E-Mail: jyudken@highroadstrategies.com
}

* Author to whom correspondence should be addressed; E-Mail: ab@millennium-institute.org; Tel.: +1-703-351-5081; Fax: +1-703-351-9292.

Received: 29 July 2009 / Accepted: 31 August 2009 / Published: 3 September 2009

\begin{abstract}
Chemicals have become the backbone of manufacturing within industrialized economies. Being energy-intensive materials to produce, this sector is threatened by policies aimed at combating and adapting to climate change. This study examines the worst-case scenario for the U.S. chemicals industry when a medium $\mathrm{CO}_{2}$ price policy is employed. After examining possible industry responses, the study goes on to identify and provide a preliminary evaluation of potential opportunities to mitigate these impacts. If climate regulations are applied only in the United States, and no action is taken to invest in advanced low- and no-carbon technologies to mitigate the impacts of rising energy costs, the examination shows that climate policies that put a price on carbon could have substantial impacts on the competiveness of the U.S. chemicals industry over the next two decades. In the long run, there exist technologies that are available to enable the chemicals sector to achieve sufficient efficiency gains to offset and manage the additional energy costs arising from a climate policy.
\end{abstract}

Keywords: chemicals; petrochemical; chlorine; alkaline; climate policy; dynamic modeling; industry competitiveness; cap and trade 


\section{Introduction}

With the growing use of chemicals in the manufacturing of goods within the economy, comes an equally large increase in the amount of energy used in the process. The chemicals industry covers a broad spectrum of bases and products used in everyday items, and the energy usage of the sector is often overlooked. When attempting to analyze such a large entity with so many facets, it becomes difficult to develop projections of future impacts of external forces. One shift that will have ramifications on this industry is the move towards carbon pricing and attempts to mitigate the negative impacts of anthropogenic emissions on the climate. When artificial costs are imposed on the industry, it is difficult to predict the outcome.

When the U.S. Department of Energy's Energy Information Administration analyzes different pieces of climate legislation it mostly calculates projected impacts on broad economic indicators, such as GDP, total consumer spending, and industrial output [1-4]. Many other studies, by environmentalists and academic economists, use general equilibrium models that also mostly yield economy-wide impacts, though some contain industrial input-out (I-O) modules, which can calculate distributional effects, mainly at a high level of sector aggregation [5].

In recognition of these challenges, the present study, which uses the Integrated Industry ModelCarbon Policy (IIM-CP), examines the carbon permits system's impacts (e.g., energy price changes resulting from a carbon-pricing policy) on the competitiveness of the U.S. chemical sector, which produces among the most energy-intensive products, and its participation in the international market. It further examines possible industry responses, and identifies and provides a preliminary evaluation of potential opportunities to mitigate these impacts.

Since the new administration has made public that it intends to approve climate legislation before the Conference of Parties (COP15) to be held in December 2009, the main body of the study proposes what can be considered the worst case scenario for the U.S. chemical industry. This is due to the boundaries of the analysis and the assumptions underlying various scenarios.

Furthermore, this partial equilibrium study hopes to build on the general equilibrium analyses already available [2-4] by researching the impacts of climate legislation on selected four to six digits NAICS (North American Industry Classification System), while avoiding the study of the broader economy-wide policy repercussions (both positive and negative).

Employing a computer-based, System Dynamics modeling approach, supplemented by econometric and qualitative analyses, the study investigates three questions:

- How will climate policy-driven energy price increases affect the production costs and profitability of manufacturers in the chemical sector?

- In the face of energy-driven cost increases, and constraints on manufacturers' ability to pass these costs along to consumers, how will international competition affect the industry's competitiveness (i.e., profitability and market share)?

- How could manufacturers respond to the energy price increases and possible threats to their competitiveness?

These questions have been examined for a selected energy price increase associated with the Climate Security Act of 2007 (S. 2191) [6], a "Mid- $\mathrm{CO}_{2}$ Price Policy" case, introduced by Senators Joseph Lieberman (I-CT) and John Warner (R-VA). EIA's analysis of the "Mid-CO ${ }_{2}$ Price Policy" 
projects the inflation-adjusted (USD 2006) allowance price to be $\$ 30$ per metric ton of $\mathrm{CO}_{2}$-equivalent by 2020 and $\$ 61$ by 2030 [2]. The AEO 2008 projects the highest price increases by 2030, under the Mid- $\mathrm{CO}_{2}$ Price Policy case, for carbon intensive energy sources, such as coal coke and metallurgical coal $(+180 \%)$, followed by residual fuel oil $(+43 \%)$, natural gas $(+39 \%)$ and distillate fuel oil $(+24 \%)$. Finally, electricity and liquefied petroleum gas will incur small and no increases, $+13.1 \%$ and $-0.1 \%$ respectively [2].

\section{Chemicals Industry Overview}

Chemicals manufacturing is one of the largest manufacturing industries in the U.S. economy. In 2006 , it shipped a total of more than $\$ 637$ billion $\left(10^{9}\right)$ worth of goods and employed 869,000 workers [7]. In 2005, there were over 9,500 firms with 13,200 establishments that manufacture chemical products, located in every state in the union. These include businesses of every size, including 1,425 medium-sized manufacturing plants with 100-500 employees, and 3,405 large facilities with more than 500 employees, which employ more than 85 percent of workers in the industry. Chemicals manufacturing is also the largest exporting sector in the U.S. economy. In 2006, the U.S. chemicals industry exported $\$ 135.1$ billion and imported $\$ 142.8$ billion producing a trade deficit of $\$ 7.7$ billion [7].

The chemicals industry produces over 70,000 products used in every sector of the economy. It is a primary supplier of intermediate inputs to agriculture, other manufacturing industries, construction, and service industries, as well as thousands of consumer goods. Major manufacturing sector customers include rubber and plastic products, textiles, apparel, petroleum refining, pulp and paper, and primary metals. It also consumes 26 percent of its own output to produce downstream products that are intermediate goods used in other industries or in end-use products.

Chemicals manufacturing (NAICS 325) has five major divisions. Its largest sector, basic chemicals (NAICS 3251), which accounted for more than a third of the total dollar output of the chemicals industry [7], consists of several smaller industrial sectors. These include inorganic chemicals (including alkalies and chlorine, industrial gases, acids and inorganic pigments), petrochemicals and derivatives (including organics), and synthetic materials, such as plastic resins, synthetic rubber, and man-made fibers.

In this study, we examined two important and highly energy intensive industries within the basic chemicals sector: petrochemical manufacturing (32511) which includes establishments that manufacture acyclic (aliphatic) hydrocarbons (ethylene, propylene, and butylenes), and cyclic aromatic hydrocarbons (benzene, toluene, styrene, xylene, ethyl benzene, and cumene) made from refined petroleum or liquid hydrocarbons; and, alkalies and chlorine (chlor-alkali) manufacturing (325181), comprised of establishments primarily engaged in manufacturing chlorine, sodium hydroxide (i.e., caustic soda), and other alkalies [8]. 
Table 1. Energy intensity* ${ }^{\dagger}$ for selected energy sectors, 2006. Industries in bold are examined in the study.

\begin{tabular}{lll}
\hline NAICS Code & Industry Sector & Energy Intensity* [Percent] \\
\hline $1-33$ & Manufacturing & 2.9 \\
325 & Chemicals Manufacturing & 5.6 \\
3251 & Basic Chemicals & 10.2 \\
$\mathbf{3 2 5 1 1}$ & Petrochemicals & $\mathbf{8 . 0}$ \\
$\mathbf{3 2 5 1 8 1}$ & Alkalies and Chlorine & $\mathbf{3 8 . 9}$ \\
331 & Primary Metals & 6.4 \\
322 & Paper Manufacturing & 7.3 \\
\hline
\end{tabular}

* Energy intensity is calculated as the share of total energy expenditures (fuel and electricity) as a share of total operating expenditures (roughly equal to sum of materials costs, labor compensation and new capital expenditures in the Census Bureau's Annual Survey of Manufactures, 2006);

$\uparrow$ Does not include expenditures on energy fuels used as manufacturing feedstock (e.g., natural gas used in petrochemical production; coke used in steel production).

\subsection{Petrochemical Manufacturing}

According to 2005 Census Bureau data [9], the U.S. petrochemical industry is comprised of 34 firms with 45 establishments employing nearly 7,400 workers, including 24 large manufacturing facilities with more than 500 employees. About 70 percent of petrochemicals and downstream derivatives are produced in facilities located in the Gulf Coast region. Because the refining industry is the major supplier of raw materials for ethylene production, more than 50 percent of all ethylene plants are located at petroleum refineries.

In 2006, U.S. petrochemical manufacturers produced 127.5 billion pounds and shipped $\$ 60.8$ billion worth of goods [10]. Ethylene is the largest volume product made by the industry. Others include propylene and benzene. These products are feedstock used in the production of a very large number of derivative chemical products, many in turn used to produce further downstream products that are inputs for many different industries. For example, ethylene is used to produce ethylene dichloride, used in turn to produce vinyl chloride, and then polyvinylchloride (PVC) used in pipes, siding, windows, pool liners and other construction items.

The U.S. petrochemical industry ended 2007 with a net trade deficit, with 3.1 million metric tons (mmt) or $\$ 2.8$ billion worth of imports, exports of $1.5 \mathrm{mmt}$ tons ( $\$ 1.6$ billion) and net imports of $1.6 \mathrm{mmt}$ ( $\$ 1.2$ billion). Trade flows between U.S. and Canadian buyers and sellers far outpaced trade with any other country. Canada is an especially large net exporter of petrochemicals to the United States. Other major trade partners include South Africa, Mexico, Norway and Belgium. 


\subsection{Chlor-Alkali Manufacturing}

The chlor-alkali industry has 29 firms with 47 establishments employing nearly 7,800 workers, including 25 establishments with over 500 employees [9]. The vast majority of chlorine production takes place in the South, where companies are located to take advantage of low electricity prices and reasonable labor costs. Chlor-alkali plants in the United States are aging. A 2000 Lawrence Berkeley National Laboratory report indicates that most U.S. chlor-alkali plants were 20-25 years old at the time, and some were considerably older [11].

U.S. chlor-alkali firms produced 32.5 million short tons, valued at $\$ 6.4$ billion [10]. Chlorine is used in downstream products (e.g., vinyl, phosphene, HCL, solvents), in water treatment and in other industrial processes, such as in pulp and paper manufacturing. Caustic soda finds applications in the production of organic chemicals, pulp and paper, inorganic chemicals, alumina refining, soaps and detergents, textiles, water treatment, food industry, among others.

The chlor-alkali industry has a large positive trade balance, with net exports of $7.2 \mathrm{mmt}$, worth $\$ 1.1$ billion. In both industries, trade flows between U.S. and Canadian buyers and sellers far outpaced trade with any other country. Canada is a net importer of U.S. chlorine and alkaline products. Other major trade partners include Mexico, Brazil, Japan, and Australia.

\section{Literature Review}

There is increasing scientific evidence indicating that the climate is going through anthropogenicinduced changes; and policymakers are beginning to take action. One of the biggest fears is the effect that an artificial rise in energy costs would have on energy-intensive manufacturing sectors. This study aims at quantifying the worst-case scenario for the chemicals industry and to evaluate whether the concerns expressed over climate legislation during the last few years are well founded.

One of the main motivations for this study is the acknowledgment that until recently the economic debate on climate policies has been supported by general equilibrium studies, and limited to macroeconomic impacts of climate policies, which investigate the broader economic impacts of a policy intervention. When the U.S. Department of Energy (DOE-EIA), and most other environmentalists and academic economists, analyze different pieces of climate legislation, they generally calculate projected impacts on GDP, total consumer spending, and industrial output [1-4]. Some other studies contain industrial input-out (I-O) modules, which can calculate distributional effects, mainly at a high level of sector aggregation [5]. The modest climate policy impacts observedfor example, from a fraction of a percent to only a couple of percent declines in GDP by 2020 or 2030 - indicate that climate policies will have small or minimal impacts on a nation's economy $[4,12]$. At worst, they show that GHG policies are likely to have significant direct impacts on coal and other domestic energy industries [2].

A relatively small number of studies have attempted to examine climate policies and their implications for manufacturing industries in much depth. One set of studies are largely qualitativethey don't quantify policy impacts on industry sectors, but include in-depth industry profiles, and evaluate different energy and climate policy options in light of industry analyses $[3,12,13]$. Another set of studies apply modeling tools in attempts to quantify these impacts [5,14-20]. Among others, the 
latter category include Resources for the Future (RFF) ongoing studies aimed at understanding how carbon-dioxide charges affect industrial competitiveness, measured as impacts on operating costs, profits, and production output [5,15]. In addition, two detailed studies of the impacts of the European Union Emissions Trading Scheme (EU ETS) on the competitiveness of European manufacturing industries provide a good degree of detail. Their focus on the other hand was on narrower, more energy-intensive industrial categories than traditional economic studies usually evaluate [16,21].

Important insights and lessons emerge from these studies, as a RFF paper notes, "the impact of a $\mathrm{CO}_{2}$ price on domestics industries is fundamentally tied to the energy (and more specifically carbon) intensity of those industries, the degree to which they can pass costs on to the consumers of their products (often other industries), and the resulting effect on U.S. production" [15]. Another concern is the carbon leakage problem: increased U.S. production costs cause energy-intensive manufacturers to shift their operations to nations that have weaker to, or do not adopt, GHG limiting policies, undermining the environmental objectives of the domestic policy.

Only a few studies over the past decade have attempted to evaluate climate policies and their impact on the manufacturing sector, especially on energy-intensive industries, using dynamic modeling tools [16-20]. This study is a new addition to this small group.

\section{Research Approach}

The research methodology employed utilized historical economic data and the construction of a substantial, System Dynamics partial equilibrium industry sector model to develop detailed economic and energy profiles of the chemical industry. Accompanied by group model building sessions, more robust modeling techniques could be developed, which in turn led to stronger and more relevant conclusions.

The System Dynamics methodology supports the representation of the context in which policies are formulated and evaluated, using feedback loops, non-linearity and delays [22]. Such properties of complex systems are explicitly analyzed and accounted for in the partial equilibrium model hereby proposed. This is particularly advised when considering that the enactment of a climate policy has no precedents in history and may trigger feedback loops generating unprecedented and unexpected behavior [23]. For this reason optimization tools, econometrics and Computable General Equilibrium (CGE) models may generate an analysis limited to historical experience, narrow boundaries and detailed complexity [23]. The IIM-CP model customized to the iron and steel sector is intended to complement existing general equilibrium studies, assessing the impacts of climate policies on selected industry segments at a level of detail (four to six digits NAICS) that cannot generally be addressed with economy-wide models.

The modeling work proposed in this study followed a three-phased approach. First, we constructed a basic production cost model for the chemicals industry. This was then extended and broadened to enable modeling of market dynamic features, that accounted for international trade flows and their impacts on the industry's bottom-lines and outputs, under the different emissions pricing scenarios and under different market assumptions (e.g., regarding cost pass along). Finally, results of the simulation helped to inform our analyses of investment and policy options, the third leg of the study, for the industry. However, although no direct modeling of investment issues was attempted, we did undertake 
a preliminary modeling of an important policy alternative aimed at offsetting cost and market impacts and we investigated needed energy efficiency improvements to offset increasing energy costs. Finally, we carried out several sensitivity simulations using our models to examine variations in our results from different assumptions about key model variables, notably materials costs, domestic and world prices, elasticities of demand and energy efficiency improvement rates.

The main baseline assumptions used to calibrate the model are contained in Table 2 below. All assumptions were discussed with industry representatives to fully incorporate their view and understanding of the market/industry in the modeling work hereby presented. Many assumptions were directly simulated and tested in real time during group modeling sessions and meetings.

Data were gathered from The U.S. Department of Energy's Industrial Technologies Program (ITP) [24] and the Manufacturing Energy Consumption Survey (MECS) [25], the U.S. Census Bureau's Annual Survey of Manufacturers (ASM) [10], the United States International Trade Commission (USITC), the U.S. Geological Survey (USGS), and Global Insight (GI), which provided data projections on market prices that were then used to define market prices and materials cost trends in the II-CPM simulations [26].

Table 2. Main industry assumptions used in IIM-CP.

\begin{tabular}{|c|c|c|c|c|}
\hline & $\begin{array}{l}\text { Market Price } \\
\text { (domestic and ROW) } \\
\text { and Material Costs }\end{array}$ & Labor Costs & $\begin{array}{l}\text { Feedstock } \\
\text { Energy } \\
\text { Costs }\end{array}$ & GDP/Demand \\
\hline Petrochemicals & $\begin{array}{l}\text { Indexed to GI prices } \\
\text { projections, } \\
3 \% \text { average growth } \\
\text { rate } 2008 / 2030\end{array}$ & $\begin{array}{l}\text { Compensation: } \\
\text { Constant in real terms } \\
\text { Labor Intensity: } \\
\text { long term trend then } \\
\text { flattens in } 2020\end{array}$ & $\begin{array}{l}\text { Natural gas } \\
\text { and LPG } \\
\text { feedstock }\end{array}$ & $\begin{array}{l}\text { Long-term trend: } \\
\text { slowly decreasing ratio. } \\
1.67 \% \text { average growth } \\
\text { rate } 1992 / 2030\end{array}$ \\
\hline Alkalies \& Chlorine & $\begin{array}{l}\text { Indexed to GI prices } \\
\text { projections, } \\
2 \% \text { average growth } \\
\text { rate } 2008 / 2030\end{array}$ & $\begin{array}{l}\text { Compensation: } \\
\text { Constant in real terms } \\
\text { Labor Intensity: } \\
\text { constant }\end{array}$ & $\begin{array}{l}\text { LPG } \\
\text { feedstock }\end{array}$ & $\begin{array}{l}\text { Long-term trend: } \\
\text { slowly decreasing ratio. } \\
0 \% \text { average growth rate } \\
1992 / 2030,0.2 \% \\
\text { growth rate after } 2007\end{array}$ \\
\hline $\begin{array}{l}\text { Other Assumptions } \\
\text { and Specifications }\end{array}$ & \multicolumn{4}{|c|}{$\begin{array}{l}\text { - Compensation: long term trend takes into account forecasted inflation (CBO/EIA) and } \\
\text { historical increase in compensation. } \\
\text { - Energy Intensity: based on MECS } 2002 \text { and energy efficiency increasing by } 0.25 \% \text { per } \\
\text { year in reference case for future projections. }\end{array}$} \\
\hline
\end{tabular}

We simulated a variety of scenarios for the chemical industry, as summarized below:

Core Scenarios. Simulations estimating the impacts of the $\mathrm{Mid}-\mathrm{CO}_{2}$ Price Case relative to BAU, assuming no cost pass-along by the industry to its customers (NCPA).

Cost Pass-Along Scenarios. Simulations of the $\mathrm{CO}_{2}$ price case relative to BAU assuming that $100 \%$ of the additional energy costs are passed along by the industry (CPA). 
Required Energy Efficiency Gains. Calculations of the energy efficiency gains required to offset the increased energy costs associated with the climate policy case relative to BAU.

Allowance Allocation. Simulations of the impact of an allowance allocations equal to 90 percent (diminishing by 2 percent per year) of the increased prices for energy consumed by the industry resulting from the $\mathrm{CO}_{2}$ price case.

\section{Climate Policy Impacts on Petrochemical Manufacturing}

Petrochemical manufacturing is one of the most energy-intensive industries in the U.S. economy, yet, according to the II-CPM simulations, the Mid- $\mathrm{CO}_{2}$ Price Policy would have very modest impacts on the industry's costs, operating surplus (profits), and operating margins (profit margins). These results reflect assumptions and contingencies, such as market price projections, energy mix data and energy price variations, and credit allocation for feedback energy use.

In any event, the U.S. petrochemical industry has long been concerned with energy costs, since its primary feedstock is derived from hydrocarbon fuels (petroleum, natural gas). Although in recent years the industry has been financially strong-at least until the current economic crisis-rising energy costs (in particular, natural gas) have prompted some large manufacturers to explore making investments in offshore facilities closer to cheaper and abundant energy supplies, rather than expanding their domestic capacity. Hence, even an incremental increase in energy costs arising from a climate policy, which would apply only the United States, could influence domestic producers' future location and investment decisions.

\subsection{Production Cost Structure (BAU—Business As Usual)}

In 2006, material costs accounted for two-thirds of total costs, energy costs for 30 percent, and labor for only 3 percent. Energy feedstock accounts for the bulk of energy costs, fuel energy accounts for just a fraction, and electricity costs are all but negligible.

Energy feedstock accounts for the largest share of the industry's energy costs. As a share of total production costs, total energy costs were about 30 percent in 2006. They were projected to fluctuate around one-quarter of the total, most years thereafter, in the BAU scenario. Total energy costs are also substantially larger than labor costs; they were about 2-3 times the latter from 1992 through 1999. They would steadily climb to 17 times greater the labor costs by 2030. Energy costs were estimated to grow from only about 30 percent to a third of materials costs in 2030. In contrast, the energy-labor ratio in policy case would rise to over 19 times, and energy-materials to 35 percent, by 2030 .

\subsection{Energy and Production Cost Impacts}

Table 3 summarizes the production cost impacts projected by the II-CPM simulations for the petrochemical industry, assuming no mitigating actions to reduce energy costs and the implementation of climate policies only in the U.S. The table shows the small cost increases above the BAU, which would rise to only 1 percent in 2020 and 1.7 percent in 2030. Yet, the energy cost share of total production costs for the industry, was 30 percent in 2006. But by 2020, it would fall to under a quarter 
of the total, only about 1 percent greater than the BAU share, where it would remain through 2030. This share would change very little under the policy case.

Feedstock accounts for the largest share of energy inputs-about 80 percent of total energy costs in 2006, compared to 18 percent for energy fuels and 3 percent for electricity (see Table 3 ).

Under the Mid- $\mathrm{CO}_{2}$ Price Policy, overall energy costs would increase by a little over 4 percent in 2020, relative to BAU, and by 7 percent in 2030. The feedstock role in the energy cost increase under the climate policy would actually shrink over time, to 75 percent of total energy costs, in 2030, only 1.2 percent over BAU. Fuel costs for heat and power would grow relatively and absolutely, under the climate policy, to 33 percent higher than BAU and would be 21 percent of total costs in 2030 . Electricity would not grow relatively to other energy sources, but would be about 13 percent higher than BAU, in 2030.

Table 3. Prduction costs, energy share and energy cost components for petrochemical manufacturing.

\begin{tabular}{|c|c|c|c|c|c|}
\hline \multirow{2}{*}{ Item } & \multirow{2}{*}{$\begin{array}{l}2006 \\
\text { Value } \\
\end{array}$} & \multicolumn{2}{|l|}{2020} & \multicolumn{2}{|l|}{2030} \\
\hline & & Value & \% above BAU & Value & $\%$ above BAU \\
\hline \multicolumn{6}{|c|}{ Production Costs (USD 2000/ton) } \\
\hline BAU & 457 & 508 & - & 506 & - \\
\hline Mid- $\mathrm{CO}_{2}$ Price Case Above BAU & - & 5 & 1.0 & 9 & 1.7 \\
\hline \multicolumn{6}{|c|}{ Energy Share of Production Costs (Percent) } \\
\hline Mid- $\mathrm{CO}_{2}$ Price Case & 29.6 & 23.2 & 0.8 & 25.3 & 1.3 \\
\hline \multicolumn{6}{|c|}{ Energy Cost Components (USD 2000/ton) } \\
\hline \multicolumn{6}{|c|}{ Mid- $\mathrm{CO}_{2}$ Price Case: } \\
\hline Total Energy Costs & 135 & 119 & 4.4 & 130 & 7.1 \\
\hline Fuel Costs & 24 & 23 & 19.0 & 28 & 33.1 \\
\hline Electricity Costs & 4 & 4 & 8.6 & 4 & 13.1 \\
\hline Feedstock Costs & 107 & 92 & 1.2 & 98 & 1.2 \\
\hline
\end{tabular}

These results reflect assumptions about the energy source used as feedstock in petrochemical manufacturing, based on the DOE's Manufacturing Energy Consumption Survey (MECS) data, which assumes that all but a small amount of energy fuel used as feedstock is liquid petroleum gas (LPG) or natural liquid gas (NLG). The study therefore assumed that all the energy feedstock was LPG using EIA price projections to characterize the climate policy impacts. A source at the American Chemistry Council (ACC) suggested to us, however, that much if not most of the fuel used as feedstock may in fact be NGL rather than LPG-especially ethane and propane-basic building blocks of ethylene and other bulk petrochemical production in the pyrolysis process. We subsequently did a rough estimate of what the cost impacts might be if it was assumed that a portion or all the feedstock energy consumed as feedstock was in fact NGL. In particular, estimates of the impacts were done assuming that 10 percent, 50 percent and 100 percent of the feedstock was actually NGL, rather than LPG. The results of this estimate showed that the changes in feedstock costs would result in increases in overall production costs relative to $\mathrm{BAU}$, but in cost declines in absolute terms, ranging from as low as 
1.2 percent above BAU to a high of 3.2 percent in 2020, and a low of 2 percent to a high of 5.5 percent in 2030. In short, if in fact U.S. petrochemical feedstock is in part, mostly or totally comprised of NGL rather than LPG, the results would range from small to modestly higher cost increases compared to the II-CPM results.

\subsection{Operating Surplus and Margins (NCPA-No Cost Pass-Along)}

Assuming NCPA seems reasonable for this sector due to its very large operating surplus and margins probably caused by the high capital-intensiveness of petrochemicals. Not surprisingly, low production costs under the climate policy would produce a small dent in industry's operating surplus, relative to BAU: there would be only a 1.2 percent reduction in the operating surplus relative to BAU in 2020, and a slightly higher, 2.2 percent, reduction in 2030.

The operating margin change under the policy case also suggests very small impacts on industry's bottom line in the II-CPM simulations, under the assumptions about fuels and prices used in the study. The modeling results showed only a 0.5 percent reduction in the operating margin in 2020 and a 1 percent reduction in 2030. In short, we should expect, at most, only a very modest reduction of the industry's profits and profit margins by 2030 as a result of a climate policy, given the feedstock energy source assumptions used in the original II-CPM simulations.

If, however, the industry actually consumed NGL as feedstock, instead of or addition to LPG, which appears likely according to industry sources, the resultant operating surplus reductions would be somewhat larger. A 10 percent NGL—90 percent LPG split would increase the operating surplus and operating margin impacts only slightly, even for the more volatile NGL price estimates. If we assume a 50-50 split, the operating surplus reduction could rise to 4 percent by 2030 , and if a 100 percent NGL feedstock is assumed in lieu of LPG, the operating surplus reduction could grow to over 5 percent relative to BAU. Significantly, the operating margin reduction could range from nearly 2 in the 50 percent NGL case by 2030 and to 3 percent for the 100 percent NGL case, in 2030. Nevertheless, in absolute terms, the operating surplus and operating margin would be higher when using NGL, due to its lower price, compared to the II-CPM original simulations of the BAU and Mid- $\mathrm{CO}_{2}$ Price Policy cases.

\subsection{Operating Surplus and Market Shares (CPA-Cost Pass-Along)}

Under favorable market conditions, low cost and high operating surplus/margin under the $\mathrm{Mid}-\mathrm{CO}_{2}$ Price Policy, petrochemical companies might decide to pass along some or all of the additional costs (CPA) from the climate policy to their customers. The operating surplus, operating margin (and therefore profit margin), and market share reductions would be very small and unlikely to threaten the industry's competitive position. Even if the NGL-LPG scenarios represent more realistic situations in the industry, the operating surplus impacts, relative to BAU would still be relatively modest and CPA may remain an option for petrochemical companies, depending on market conditions at the time. In any case, whatever the impacts, under Mid- $\mathrm{CO}_{2}$ Price Policy (the core Lieberman-Warner proposal) it is likely that a credit would be given to the petrochemical industry for feedstock energy use, which would mitigate the economic impacts of the climate policy on the sector. 
The extent to which the industry can pass along the added costs of feedstock and energy fuels under a climate policy would depend on the strength of domestic and international demand, the intensity of international competition, the extent of production oversupply, and the availability and price volatility of the primary feedstock. The petrochemical manufacturing is a global industry, which is especially sensitive to the availability and costs of raw materials, primarily hydrocarbons mostly sold on world markets. The prices of petrochemical products are strongly correlated-some say as much as 80 percent - with the cost of crude oil. As a consequence, the industry is subject to a great deal of price volatility, tied to the price fluctuations of petroleum and natural gas.

\section{Technology and Policy Options-Petrochemicals}

Given the relatively low economic impacts from the Mid- $\mathrm{CO}_{2}$ Price Policy on the petrochemical industry projected by the II-CPM, even with different assumptions regarding feedstock use (i.e., NGL versus LPG), the energy-efficiency requirements to offset these cost impacts would be modest-only about 1 percent through 2030. Although, it remains in the industry's interest to continue investigating new energy-saving technology improvements, from short-term incremental improvements to longerterm advanced or alternative process technologies.

\subsection{Technology Options}

According to the ACC, the chemicals industry has made substantial improvements in energyefficiency over the past thirty years. One index indicates that the industry's energy intensity has declined by about 60 percent between 1974 and 2006, and a reduction in GHG intensity of about 40 percent in the same period. Further incremental improvements may be possible — and perhaps might be sufficient to offset the climate policy cost impacts, as long as they are as small as indicated in the II-CPM simulation results. Larger scale energy-efficiency improvements might require substantial investments over a longer time period, in more advanced process technology improvements, and perhaps prevalent in the substitution of existing petrochemical production processes with low-carbon alternatives.

Some technologies that could be explored are Combined heat and power generation (CHP) - the simultaneous generation of electricity and heat from a facility that is located very close to the manufacturing facility — and the substitution of fossil-fuel feedstock by biomass.

\subsection{Policy Options to Mitigate Impacts}

The implementation of a 90 percent allocation allowance to offset energy price increases under the climate policy would greatly alleviate any economic impacts of a climate policy on the petrochemical industry. But with such low impacts projected by the II-CPM, it is not clear whether such an allocation should be applied in this case. On the other hand, more research is needed to determine the actual mix of feedstock energy sources used by the industry and the past and expected in the future, and make new assessment of the cost impacts resulting from the climate policy. In any case, whether LPG or NGL are used as feedstock, the carbon content would be sequestered in petrochemicals products, 
rather than emitted as $\mathrm{CO}_{2}$, which under the Mid-Price Policy (Lieberman-Warner) would be compensated with a credit to the industry, to offset the cost impacts.

\section{Climate Policy Impacts on Chlor-Alkali Manufacturing}

In contrast to petrochemical manufacturing, the chlor-alkali manufacturing industry is among the most susceptible industries to the impacts of climate policy on its profits and competitiveness. According to the II-CPM results, chlor-alkali would experience the second largest cost increase and third largest operating surplus reduction relative to $\mathrm{BAU}$, under the Mid- $\mathrm{CO}_{2}$ Price Policy. This industry's manufacturing processes are heavily reliant on both electricity and fuels for heat and power. At the same time, it is the least sensitive to foreign imports-and the only industry with a consistent trade surplus - and therefore possibly more able to pass the policy-driven costs along in efforts to maintain its profitability.

On the other hand, basic chemicals, such as chlorine and caustic soda, produced in this industry are often upstream raw materials used in the production of downstream chemical products by the same company and at the same facilities. Manufacturers therefore would have to weigh whether it is more cost-effective to continue internal production of an increasingly expensive feedstock, or look elsewhere (i.e., offshore) for less expensive sources — or, alternatively, consider investment in newer, more energy-efficient chlor-alkali production technologies (e.g., the membrane cell).

\subsection{Production Cost Structure (BAU)}

Figure 1 presents the historical trends and projections for the production cost components for the chlor-alkali manufacturing processes in the BAU case. It also shows the additional energy costs that the industry would have to bear if the Mid- $\mathrm{CO}_{2}$ Price Policy were enacted. As with the other industries, materials costs constitute the largest share of total production costs-fluctuating around 40-45 percent for the historical period and in the projections through 2030. But the share of energy costs, and to a less extent of labor costs, also are sizable. The former have fluctuated around 40 percent historically, but were projected to fall to a little over a third of total costs. The jump in labor costs in 2005 paralleled the rise in materials costs, and a comparable growth in energy costs, all of which were then projected to remain somewhat higher than their values in prior years. Labor costs have historically been around one-fifth of total costs, and were projected to remain at that level through 2030, for BAU.

The costs of energy for the BAU case are estimated to be in the range of double the costs of labor through 2030, and nearly 2.5 times greater under the $\mathrm{Mid}-\mathrm{CO}_{2}$ Price Policy. For the BAU case, energy costs ranged from 80 percent to roughly equal materials costs from 1992 through 1999, and then fluctuated between 100-150 percent through 2008. They then were projected to fall to, and stay at, roughly three-quarters materials costs through 2030 for the BAU case. They would be a little higher relative to materials costs under the climate policy, ranging between 80-100 percent between 2009 and 2030. 


\subsection{Energy and Production Cost Impacts}

Energy cost increases under a climate policy would be fairly significant according to the II-CPM. As Table 4 shows, total production costs would grow 5.5 percent by 2020 and nearly 10 percent by 2030, compared to BAU. The energy share of total production costs was 38 percent in 2006. It was projected to remain roughly the same for BAU throughout the period when the Mid- $\mathrm{CO}_{2}$ Price Policy would be in effect. However, the modeling results show that this share would grow nearly to 42 percent, 6 percent above BAU by 2030 .

The role of the two main energy components responsible for this growth is externally purchased fuel energy and electric power. Fuel costs would account for the larger portion of the rise in energy costs and consequently the overall growth in production costs. They represent about 60 percent of total energy costs and would increase by over a fifth by 2020 and over one-third by 2030, relative to BAU. Natural gas is the primary fuel consumed in the industry, followed by coal and LPG. The large price increases for the two former fuels under the climate policy are responsible for almost all the growth in fuel costs for chlor-alkali relative to BAU. Electricity growth is much more modest, rising only by 13 percent above BAU by 2030. This reflects the relatively moderate price increases for that energy source under the Mid- $\mathrm{CO}_{2}$ Price Policy.

Figure 1. Chlor-Alkali real unit production cost components, business as usual, 1992-2030.

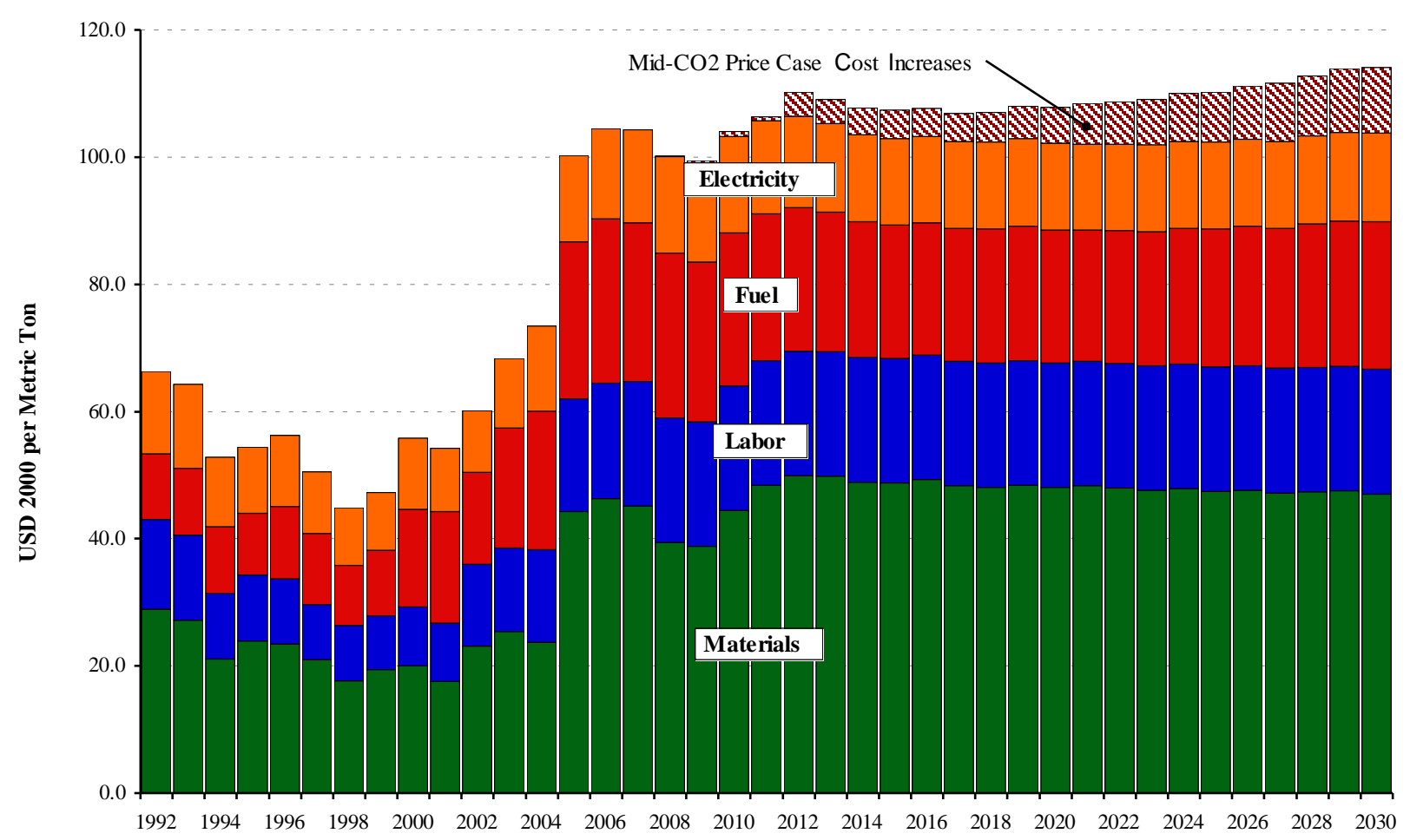

\subsection{Operating Surplus and Margins (NCPA)}

The chlor-alkali's operating surplus, assuming NCPA, is quite large in the BAU case, but, it would shrink by a sizable amount under the Mid- $\mathrm{CO}_{2}$ Price Policy. This is partly the result of projected declining market price relative to the rapidly rising production cost curve under the climate policy. 
The reduction in the industry's operating surplus resulting from the $\mathrm{Mid}-\mathrm{CO}_{2}$ Price Policy would be substantial, 10 percent below BAU in 2020 and a shade under 20 percent in 2030. Operating margins also would shrink, by 3.6 in 2020 and 6.6 percent in 2030. The growing scale of both the operating surplus and operating margin reductions, over this period could begin to translate into a noticeable diminishment in the industry's profitability, leading chlor-alkali producers to seriously explore options for containing their energy costs, contingent on its financial situation and market conditions.

Table 4. Production costs, energy share and energy cost components-chlor-alkali manufacturing.

\begin{tabular}{llllll}
\hline \multirow{2}{*}{ Item } & $\mathbf{2 0 0 6}$ & $\mathbf{2 0 2 0}$ & \multicolumn{2}{l}{$\mathbf{2 0 3 0}$} \\
\cline { 2 - 7 } & Value & Value & \% above BAU & Value & \% above BAU \\
\hline Production Costs (USD 2000/Mt) & 104 & 102 & - & 104 & - \\
\hline BAU & - & 6 & 5.5 & 10 & 9.9 \\
Mid-CO 2 Price Case Above BAU & - & & & \\
\hline Energy Share of Production Costs (Percent) & & & \\
\hline Mid-CO 2 Price Case & 38.3 & 37.3 & 3.5 & & \\
\hline Energy Cost Components (USD 2000/Mt) & & & \\
\hline Mid-CO 2 Price Case: & 40 & 40 & 16.3 & 27.6 \\
Total Energy Costs & 26 & 25 & 21.3 & 32 & 36.6 \\
Fuel Costs & 14 & 15 & 8.6 & 16 & 13.1 \\
Electricity Costs
\end{tabular}

$\mathrm{Mt}=$ Metric Ton $[=1.102$ Short Tons $]$

\subsection{Operating Surplus and Market Shares (CPA)}

Faced with diminishing profitability, the industry might also consider passing along the costs to customers (CPA), to preserve its profit margins and minimize operating surplus reductions. But with higher prices come lower market shares, as the lower cost of foreign imports replaces domestic production and sales. Because the chlor-alkali industry currently enjoys a net trade surplus (exports exceeds imports), the pressures of foreign competition may not be as great as for other industries, and cost pass-along may be more of an option.

Under the cost basis CPA assumption, the industry would see a decline of less than 1 percent of its domestic market share, which would still total around 90 percent, as a result a CPA choice under the Mid- $\mathrm{CO}_{2}$ Price Policy. This is equivalent to a reduction in production of 270,000 metric tons of chlor-alkali products, out of a total net domestic output of 34.6 million metric tons. The industry's operating surplus also would be diminished by less than 1 percent, which would translate into a negligible impact on its profits.

Given the revenue reduction projected under a NCPA assumption, and the projected gains if costs were passed along, manufacturers in the chlor-alkali industry may decide to pass along some or all their additional costs, despite modest losses in market shares. Given the low import vulnerability of this industry - up until now it has been a net exporter — cost pass-along may be a reasonable response by chlor-alkali producers to offset and prevent future major economic harm. But market conditions 
could greatly influence chlor-alkali companies' decisions about passing along cost increases or investment choices in response to them.

\section{Technology and Policy Options-Chlor-Alkali}

In the study, we reviewed some of the technology investment options and evaluated a public policy option that could help the chlor-alkali industry mitigate the economic costs of a climate policy. We first found that the industry would need to achieve fairly substantial energy-efficiency gains to offset these costs.

At the same time, although there are incremental heat, power and process technologies and a major process technology that the industry already is moving towards, which could greatly reduce the industry's energy costs, there remain barriers to their successful implementation. More research is needed to evaluate these options, their potential for generating sufficient energy-savings, and the timing, cost, and technical barriers to their successful implementation.

Finally, we found that a 90 percent allowance allocation policy would alleviate some of the shortto-mid-term cost pressures on U.S. chlor-alkali manufacturers, which could buy time, if not encourage them to make the transition to new energy-saving technologies and advanced chlor-alkali manufacturing processes.

\subsection{Energy Efficiency Requirements}

Figure 2 illustrates the energy efficiency gains that would be required in the chlor-alkali industry to offset the production costs that would result from the Mid- $\mathrm{CO}_{2}$ Price Policy. The largest gains required would be to offset fuel energy cost increases. These rise from a little over 10 percent in 2012, immediately after the policy would go into effect, to about 19 percent in 2030. Electricity gains required would be around 7 percent in 2020 and 10 percent in 2030. Because fuel costs are the primary source of cost increases in the chlor-alkali industry, according to the II-CPM simulations, the primary emphasis on energy-saving measures and technologies should be on making efficiency improvements in the delivery and use of heat and power.

\subsection{Technology Options}

According to the International Energy Agency (IEA) [27], the best opportunity for reducing energy use and costs of the chlor-alkali industry is to substitute membrane technologies for the mercury and diaphragm production methods currently in place. Membranes are a chemical separation process that is among the most energy-intensive operations in the chemical industry, which includes distillation and extraction. They use up to 40 percent of all energy consumed in the chemical industry and can account for more than 50 percent of plant operating costs. If the current membranes cells are replaced by more advanced cells using new state-of-the-art technology (i.e., the oxygen-consuming cathode), energy savings of at least 30 percent could be realized. 
Figure 2. Chlor-Alkali industry-cumulative yearly energy efficiency gains required to offset climate policy costs.

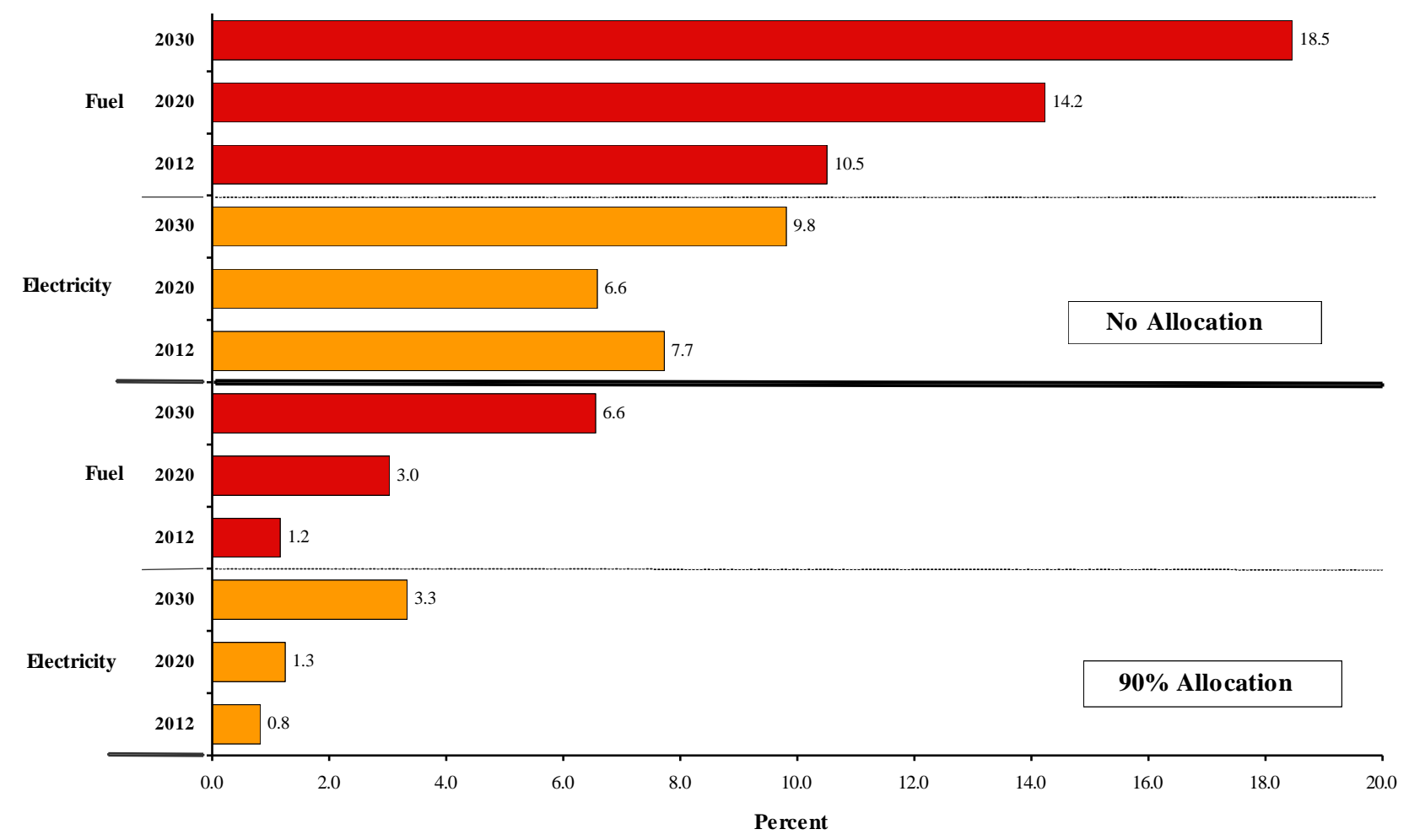

However, because of the relatively low cost of electricity in past years and the high capital investment required, U.S. firms have been resistant to invest in the new energy-efficient chlor-alkali process, unless there is a short-term boost to their competitiveness. At the same time, investments in the new technology have already been made in Europe and Japan, where energy prices are higher and environmental regulations stricter than in the United States (FY 2004). U.S. electricity prices, however, have risen over the past decade, which would be augmented by a climate policy. Coupled with sufficient investment incentives, this may provide some encouragement for U.S. chemical companies to make the transition to new cell technologies.

\subsection{Policy Options to Mitigate Impacts}

Figure 2 also illustrates the potential mitigating benefits of the 90 percent allocation measure on the economic impacts of the Mid- $\mathrm{CO}_{2}$ Price Policy on the industry. The cumulative energy efficiency gains required for both fuel and electricity in the allocation case would be only about one-tenth than that needed if there were no allocation, in 2012. By 2020, the requirements in the allocation case would be one-fifth that of the no allocation case, and by 2030, the requirement would fall to one-third the allocation case. The diminishing mitigating effects over time reflect the 2 percent annual reduction in the allocation offset.

Similarly, results show the substantially lower cost increase and operating surplus reduction that would result from implementing the allocation measure. The chlor-alkali industry would realize a 74 percent gain in 2020 and a 54 percent gain in 2030. By 2020, real unit production costs would fall 
from 5.5 percent to 1.5 percent, above BAU, and operating surplus would diminish from 10 percent to about 3 percent, below BAU. By 2030, production costs would shrink from 10 percent to 4.6 percent above BAU, and operating surpluses would decline from nearly 20 percent to 9 percent, below BAU.

\section{Conclusions}

The II-CPM simulations results show that enactment of a mid-price climate policy would have widely different impacts on the petrochemicals and chlor-alkali industries. Although both industries are highly energy-intensive - the former heavily dependent on hydrocarbon-based feedstock, the latter on natural gas and electricity - the different energy mixes and the projected price variations for their primary energy sources under the climate policy result in, on the one hand, relatively small impacts on the petrochemical industry, yet large and potentially troubling impacts on the chlor-alkali industry, on the other.

Under the assumptions regarding the nature of the energy mix and prices used in the II-CPM simulations and with no mitigating action being implemented to reduce the impact of a climate policy, the petrochemical industry would experience very modest increases its production costs, which would translate into only small reduction in its operating surpluses, operating margins, and ultimately its profits. In contrast, the chlor-alkali industry would experience large impacts.

At the same time, because both industries are relatively less sensitive to import substitution, under favorable market conditions, when demand is robust and prices for their goods are rising domestically and internationally, they may more easily be able to pass-through their costs to users of their products. However, both industries are more vertically integrated with producers of derivative and downstream products that rely on the processing and incorporation of their products (e.g., PVCs), than other sectors analyzed in this study. The downstream producers tend to be more price sensitive and perhaps less able to pass-through new costs in the global markets they operate within, than their basic materials suppliers. Therefore, to fully understand the implications of climate policy-driven energy cost increases, it might be necessary to examine the ripple effect of petrochemical and chlor-alkali cost increases, if they are passed through, on the profitability and competitiveness of their major downstream customers.

Both industries are also very sensitive to the volatility of energy prices, in particular, natural gas, which under conditions of weakened demand and falling product prices, have led some chemicals firms - especially in petrochemicals - to consider building new capacity in, or sometimes shifting their operations to, foreign locations with abundant and cheap energy supplies, rather than upgrading or expanding their domestic facilities. Cost pass-along in these situations is less feasible, and even incremental impacts on production costs and profits from a climate policy could influence firms' location and investment decisions, in efforts to maintain their margins.

Our examination of technology and policy options found that corresponding to the II-CPM cost, operating surplus, and profit margin findings, the petrochemical industry would require small energyefficiency gains to offset rising climate policy-driven energy costs. The required gains for the chloralkali industry, in any case, were estimated to be quite large, consistent with the substantial cost and profit impacts projected by the II-CPM. 
Both shorter and longer-run energy-saving technology options are available to the industries-and being researched by them - but the usual financial, technical, and timing issues need to be addressed to determine the economic feasibility of implementing these options, under the additional energy cost pressures from a climate policy. Both industries could benefit from incremental improvements from continued application of CHP, heat recovery, advanced sensors and process controls, and similar energy-saving applications. These in principle could help offset the relatively projected modest cost impacts in the petrochemical industry, and could help over the short-run if they were implemented in the chlor-alkali industry.

However, the larger longer-term technology improvements-membrane cells in chlor-alkali, more advanced cracking furnaces, biomass feedstock in petrochemical manufacturing-needed to offset the industries' more substantial profit reductions in later years, would require more research, development and demonstration of their technical and commercial feasibility, before companies would be willing to make the substantial investments required to replace their older, existing production facilities. At the same time, because the domestic chlor-alkali industry reportedly is characterized by aging, and in some cases very old, plants, the industry may be more ready to replace some or most existing capacity with modernized, advanced membrane cells over the next decade or so, though other enabling policies may also be needed.

Finally, the enactment of the 90 percent allowance allocation measure would greatly mitigate the cost impacts of the Mid- $\mathrm{CO}_{2}$ Price Policy for both industries, though the issue is disputable if the industry were to receive a credit for the carbon "sequestered" in its products. The allocation policy also would be important to mitigate short-to-medium term impacts on the chlor-alkali industry. In any event, we believe that other, supplemental policies might be needed to encourage chemicals manufacturers to adopt both incremental and advanced low-carbon and low-emissions process technologies over the next 10-15 years, to help them cope with increasing energy prices.

\section{References}

1. Paltsev, S.; Reilly, J.M.; Jacoby, H.D.; Gurgel, A.C.; Metcalf, G.E.; Sokolov, A.P.; Holak, J.F. Assessment of U.S. Cap-and-Trade Proposals; MIT Joint Program on the Science and Policy of Global Change: Boston, MA, USA, 2007; Report 146.

2. U.S. Department of Energy. Energy Market and Economic Impacts of S. 2191, the LiebermanWarner Climate Security Act of 2007; Energy Information Administration: Washington, DC, USA, 2008.

3. U.S. Department of Energy. Energy Market and Economic Impacts of S. 1766, the Low Carbon Economy Act of 2007; Energy Information Administration: Washington, DC, USA, 2007.

4. U.S. Department of Energy. Energy Market Impacts of Alternative Greenhouse Gas Intensity Reduction Goals; Energy Information Administration: Washington, DC, USA, 2006.

5. Morgenstern, R.D.; Ho, M.; Shih, J.-S.; Zhang, X. The near-term impacts of carbon mitigation policies on manufacturing industries. Energ. Policy 2004, 32, 1825-1841.

6. U.S. Congress. America's Climate Security Act of 2007; Washington, DC, USA, 2007.

7. American Chemistry Council (ACC). 2007 Guide to the Business of Chemistry; Washington, DC, USA, 2007. 
8. Chlistunoff, J. FY 2004 Materials, Glass, and Sensors Project and Portfolio Review, Advanced Chlor-Alkali Technology Project; Project Summary Form (CPS1797), Los Alamos National Laboratory: Los Alamos, NM, USA, 2005.

9. U.S. Census Bureau. 2005 Statistics of U.S. Businesses (SUSB); Company Statistics Division: Washington, DC, USA, 2005.

10. U.S. Census Bureau. Annual Survey of Manufactures: Statistics for Industry Groups and Industries: 2006; ASM Industry Groupings: Washington, DC, USA, 2006.

11. Worrell, E.; Phylipsen, D.; Einstein, D.; Martin, N. Energy Use and Energy Intensity of the U.S. Chemical Industry; Environmental Energy Technologies Division, Ernest Orlando Lawrence Berkeley National Laboratory: Berkeley, CA, USA, 2000.

12. Hauser, T.; Bradley, R.; Childs, B.; Werksman, J.; Heilmayr, R. Leveling the Carbon Playing Field: International Competition and US Climate Policy Design; Peterson Institute for International Economics: Washington, DC, USA, 2008.

13. McKinsey Global Institute. Curbing Global Energy Demand Growth: The Energy Productivity Opportunity; McKinsey\&Company: San Francisco, CA, USA, 2007.

14. Davidsdottir, B.; Ruth, M. Pulp non-fiction: dynamic modeling of industrial systems. J. Ind. Ecol. 2005, 9, 191-211.

15. Morgenstern, R.D.; Aldy, J.E.; Herrnstadt, E.M.; Ho, M.; Pizer, W.A. Competitiveness Impacts on Carbon Dioxide Pricing Policies on Manufacturing; Resources for the Future: Washington, DC, USA, 2007.

16. Reinaud, J. Industrial Competitiveness under the European Union Emissions Trade Scheme; International Energy Agency: Paris, France, 2005.

17. Ruth, M.; Amato, A.; Davidsdottir, B. Impacts of market-based climate change policy on the US iron and steel industry. Energ. Source. 2000, 22, 269-280.

18. Ruth, M.; Amato, A.; Davidsdottir, B. Carbon emissions from US ethylene production under climate change policies. Environ. Sci. Technol. 2002, 36, 119-124.

19. Ruth, M.; Amato, A.; Davidsdottir, B. Climate change policies and capital vintage effects: the cases of US pulp and paper, iron and steel and ethylene. J. Environ. Manage. 2004, 7, 221-233.

20. Ruth, M.; Davidsdottir, B.; Laitner, S. Impacts of energy and carbon taxes on the US pulp and paper industry. Energ. Policy 2000, 28, 259-270.

21. McKinsey \& Company and Ecofys. EU ETS Review, Report on International Competitiveness; European Commission, Directorate for Environment: Brussels, Belgium, 2006.

22. Sterman, J.D. Business Dynamics: Systems Thinking and Modeling for a Complex World; Irwin/McGraw-Hill: Boston, MA, USA, 2000.

23. Sterman, J.D. A skeptic's guide to computer models. In Managing a Nation: The Microcomputer Software Catalog; Barney, G.O., Ed.; Westview Press: Boulder, CO, USA, 1988; pp. 209-229.

24. U.S. Department of Energy. DOE/ITP Industrial Technologies Program; Office of Energy Efficiency and Renewable Energy: Washington, DC, USA, 2005.

25. U.S. Department of Energy. Manufacturing Energy Consumption Survey; Energy Information Administration: Washington, DC, USA, 2002.

26. Global Insight. Producer Price Index (PPI), Iron and Steel, updated 06 September 2008. 
27. International Energy Agency (IEA). Energy Technology Perspectives 2006, Scenarios \& Strategies to 2050; IEA: Paris, France, 2006.

(C) 2009 by the authors; licensee Molecular Diversity Preservation International, Basel, Switzerland. This article is an open-access article distributed under the terms and conditions of the Creative Commons Attribution license (http://creativecommons.org/licenses/by/3.0/). 